\title{
Legal Framework Modifications for Contaminated Sites Management in Peru
}

\author{
Izarelly Rosillo Pantoja \\ Universidad Autónoma de Querétaro, Santiago de Querétaro, Mexico
}

\begin{abstract}
The comprehensive management of contaminated sites has become a high-priority matter in governments' agendas, due to increased environmental, sanitary, social, and economic impacts. The establishment of legal dispositions is fundamental to preventing the creation of contaminated sites by hazardous waste materials. This analysis proposes an amendment in the legal framework regarding contaminated sites management in Peru, complying with the following two approaches: the regulation and control of the environmental management of hazardous materials, throughout their entire life cycle, including the phase when they become hazardous waste; and the response to emergencies caused by dumping or accidental spilling of such materials and wastes, to support immediate cleaning actions for the recovery of damaged sites. These approaches come with a systematic and holistic vision, concerning mainly a precautionary principle; its objective is to forestall damage.
\end{abstract}

Keywords: contaminated sites management, remediation, rehabilitation, law

The management of contaminated sites is usually regulated by environmental or sanitary framework dispositions, or by sectoral laws as those related to hazardous and non-hazardous solid waste management. It is possible to complement these regulations with preventive measures, making them cover activities that carry in them a risk of generating contaminated sites.

Making operating licenses for all new projects dependent on the evaluation of environmental impact would create a mechanism for preventing environmental liabilities. Financial guarantees would make resources available in case of environmental damage, thus allowing for a quick clean-up if activities should be suspended.

This bill stands within the Mexico-Germany Trilateral Cooperation, aimed at providing resources to encourage sustainable development in third-party countries, contributing to regional integration. This program is based upon the usage of common knowledge and expertise, institutional, and financial resources in countries of Latin America. The Peruvian environmental authorities requested the Mexican authorities and the German International Cooperation Agency (GIZ) to aid them in strengthening the management of sites contaminated by hazardous waste materials. Peru seized Mexico's experiences in regulating these sites. In reply to this request, a project was created to strengthen Peru's legal framework by incorporating certain regulatory dispositions in the management of contaminated sites with hazardous materials, to repair and relieve environment and health risks.

Corresponding author: Izarelly Rosillo Pantoja, Bachelor of Laws, MA in State and Municipal Public Administration, Ph.D. candidate in law, Universidad Autónoma de Querétaro, Mexico, exercised several functions in private companies as manager and legal director, and teaches at Universidad Autónoma de Querétaro, advisor in environmental law, litigation attorney and technical secretary at Querétaro’s Network for Handling Waste (REQMAR, A.C.); research fields: constitutional, notarial law, and Amparo. E-mail: izarellyrosillo@msn.com; irosillo@enlaw.net. 


\section{National Environmental Policy Regarding Contaminated Sites in Peru}

The Peruvian environmental authorities have expressed their concern over including the management of contaminated sites into their legislation, in order to reduce environmental and sanitary damages. This would allow them to comply with what their constitution establishes as environmental protection and would enhance the universal protection of human rights under the pro homine principle.

The Environmental Ministry (MINAM) is the one body authorized to establish the environmental policy of Peru. It was created on May 14, 2008, in the 101 legislative decree, to coordinate environmental policy among local, regional, and national branches of government. The MINAM considers sustainable growth primordial, as well as social justice, the preservation of natural resources and the wellbeing of the environment. These issues are a challenge for Peru, as they are listed in the country's constitutional dispositions, its international treaties and trade agreements, and the United Nations' millennium development goals ${ }^{1}$.

The creation of MINAM was a milestone in the country's environmental institutionalization. It was a state's response to the national and international challenges to reach sustainable development. The MINAM leads the National Environmental Plan of Action 2011-2021 (PLANAA) and the National Environmental Action Agenda. In May 2009, the National Environmental Policy was approved, as a means of environmental management. The environmental policy is part of the National Policy. As such, all entities comprising the National Environmental Management System (SNGA) are bound to comply with its dispositions. It was under these circumstances that the National Environmental Plan of Action (PLANAA) was created. The PLANAA is a long-term environmental planning instrument, which started with a diagnosis of the management of natural resources and Peru's opportunities to make use of them².

The comprehensive management of contaminated sites is part of the PLANAA's objectives. The plan applies the principle of shared but differentiated responsibility, which means all state entities are in charge of securing the economic resources necessary to implement PLANAA, making them resort to private sector actors. This was the way in which Peru's legal framework for contaminated sites was strengthened. It was necessary to create a solid and reliable legislation, one that would bring certainty to citizens by diminishing environmental and sanitary liabilities.

\section{Importance of the Regulation of Contaminated Sites}

Peru is one of 17 megadiverse countries in the world. It has the second largest extension of rainforests in Latin America (after Brazil), it is the most diverse country in butterfly species (with 3,700), the second most diverse in bird species $(1,835)$, the fourth in amphibians (538), and the fifth in reptiles (421). Peru also holds nearly 20,000 species of flowering plants, 1,070 species of marine fish, and 1,011 species of continental fish. According to the Convention on Biological Diversity (CBD), Peru undertakes the responsibility to protect and preserve its biological diversity. With this in mind, it created a National Strategy of Biologic Diversity (ENDB). In the said strategy, Peru recognizes the need to establish measures to preserve and restore biologic diversity, in addition to promoting the commitment and involvement of society. In this sense, comprehensive waste

\footnotetext{
${ }^{1}$ Environmental Ministry. Consulted on March 20, 2013 at http://www.minam.gob.pe/index.php?option=com_content\&view= article\&id=3\&Itemid=3.

2 Environmental Ministry, Plan Nacional de Acción Ambiental, consulted on March 20, 2013 at http://www. legislacionambientalspda.org.pe/index.php?option=com_content\&view=article\&id= 822\&Itemid=5317.
} 
management is considered as a high-priority tool for complying with PLANAA and ENDB ${ }^{3}$.

Soils and aquifers have been contaminated with hazardous materials released into the environment by mining, oil extraction, and industrial activities, without proper clean-up interventions. As this has happened, environmental liabilities have been generated, which have put human beings and other organisms in danger of health and reproductive alterations. The main goal of the resulting legal dispositions is to establish a basis for sanitation, remediation, rehabilitation, and recovery of environmental resources. The dispositions protect the quality of soils and aquifers, as well as the proper conditions needed for the protection of flora and fauna. These are the legal assets that must be defended. The human right to a healthy environment must be protected.

Sites contaminated by hazardous waste — such as that generated by mining and oil industries—are generally taken care of. However, non-hazardous waste can also affect soil capacity. These damages are often overlooked by regulations. Governments, as guarantors of social wellbeing, are obligated to regulate the management of contaminated sites. They should make the guarding of a healthy environment their objective, thus elevating quality of life and protecting fundamental rights broadly.

\section{Comprehensive Management of Contaminated Sites in Peru}

The comprehensive management of contaminated sites is usually regulated by environmental or sanitary framework dispositions, or by sectoral laws such as those dedicated to hazardous and non-hazardous waste management. Because of this, it is possible to ensure that they include regulatory measures of activities that convey a risk of generating contaminated sites. They should also hold in them a preventive quality, one that minimizes the possibility of risk.

Usually, sites contaminated by mining or oil-extraction activities are far away from populated areas, whereas those contaminated by processing industries or services are located in urban areas. The former involves contamination by toxic metals (in mining) or hydrocarbons (in oil extraction); the latter involves contamination by toxic and hazardous substances.

To propose a legal framework for the comprehensive management of contaminated sites, it was necessary to identify the governmental authorities, legal dispositions, and management instruments pertaining to the prevention, remediation, and rehabilitation of contaminated sites in Peru. Afterwards, meetings were conducted with the corresponding authorities. This allowed us to identify the areas of opportunity and the authorities' concerns. The Mexican experience in the General Law for the Prevention and Comprehensive Management of Waste (LGPPGIR) of 2003 was useful to us. This law regulated the prevention of contaminated sites in Mexico for the first time, as well as its proper remediation. The said law was fully fledged by 2006. It was complemented with technical norms that set limits to the concentration of certain pollutants and voluntary norms that set methods of analysis. Both the strengths and limitations of the LGPPGIR are taken into account for the Peruvian proposal.

As the research took place, the necessity of identifying the most common forms of site contamination in Peru became paramount. The existent legal dispositions to regulate the prevention and control of contamination by mining, oil extraction, processing, and other relevant sectors were also identified. For this means, the author utilized the geographical references of the National System of Contaminated Sites, which showed location and current situation of the said sites.

3 Environmental Ministry, Plan Nacional de Acción Ambiental, consulted on March 20, 2013 at http://www. legislacionambientalspda.org.pe/index.php?option=com_content\&view=article\&id= 822\&Itemid=5317. 
The following are some of the elements considered to form the proposal for the Peruvian legal framework:

(1) What the legal dispositions respond to (objective);

(2) Which legal terminology is needed for its enforcement (definitions or glossary of basic terms repeated in text);

(3) Who must comply (extent of enforcement);

(4) Which are the principles guiding its fulfillment;

(5) Which dispositions are of public interest;

(6) Which faculties and responsibilities pertain to the authorities intervening in its enforcement;

(7) Which are the obligations for the parties subject to verification of compliance and what might be their sanctions if they were to fail compliance;

(8) Which management instruments provide for the enforcement of the legal dispositions;

(9) How will the management be in different types of polluted sites;

(10) Which is the procedure for characterization, remediation, and rehabilitation of the contamination sites and how to proceed;

(11) Which are the prohibitions, conditions, and controls applicable during the execution of remediation and rehabilitation.

After these considerations, the inclusion of the comprehensive management of contaminated sites into the national regulation was thought to be plausible. This proposal was added in a special chapter regarding the comprehensive management of contaminated sites, with the intention of developing a future regulation on the subject. Observations were made to legal dispositions, pointing at the necessity of reform related to the rehabilitation of sites contaminated by waste not classified as hazardous. Currently, this law proposal is being discussed, with approval underway.

\section{Conclusions}

Protecting the human right to a healthy environment is the duty of all public, social, and private sectors. The state, by means of its corresponding authorities, should guarantee, protect, and if necessary repair the violation of this fundamental right. The society should respect its obligations, established in the legal system, in order to diminish environmental damage and avoid hazards against both the environment and third parties. Therefore, the right to a healthy environment should be secured by all human beings; just like other fundamental rights, it does not discriminate in matters of gender, beliefs, or social condition.

The comprehensive management of contaminated sites is a tool for the protection of the right to a healthy environment. Its correct application and supervision allow for an improved quality of life. Everyone can benefit from this, but especially those who are most marginalized, as they often live in polluted or risky areas.

The law is not an end in itself; it does not solve every problem. But the law does encourage change, which in turn strengthens actions in favor of the environment. In the case of comprehensive waste management, the law helps to reach sustainable development by means of diminishing environmental liabilities. This is why countries that do not have legislation regarding contaminated sites should develop a legal framework in this matter. The framework should establish the basic rules for regulating environmental sanitation, rehabilitation, and remediation of contaminated sites. It should also identify the instruments necessary to manage this regulation, as well as issue the necessary plans, programs, manuals, licenses, and financial incentives. Further diagnoses and protection parameters could allow for a full implementation of the National Policy for the 
Comprehensive Management of Contaminated Sites. Thus, our environmental heritage could be safeguarded and health hazards diminished, guaranteeing the human right to a healthy environment.

\section{References}

Congress of Mexico. (2003). General law for the prevention and management of waste. Retrieved from http://www.diputados. gob.mx/LeyesBiblio/pdf/263.pdf

Constitution of the United States of Mexico. (1917). Retrieved from http://www.diputados.gob.mx/LeyesBiblio/pdf/1.pdf

Cortinas de Nava, C. (2007). Citizen empowerment and comprehensive waste management. Ecology, Environmentalism, Sustainability. Retrieved from http://www.cristinacortinas.net/index.php?option=com_content\&task=view\&id=42\&Itemid $=27$

Environmental Ministry. (n.d.). Plan Nacional de Acción Ambiental (National environmental action plan). Retrieved from http://www.legislacionambientalspda.org.pe/index.php?option=com_content\&view=article\&id= 822\&Itemid=5317

Information Center of the United Nations. (n.d.). Human rights. Retrieved from http://www.cinu.org.mx/ninos/html/onu_n3.htm

Leff, E. (2004). Environmental rationality: The social appropriation of nature. Mexico: Siglo XXI.

National Supreme Court of Justice. (2010). Jurisprudence and related theses. Mexico: SCJN.

Rabasa, E. (2007). The constitution and the environment. Mexico: UNAM.

Rosillo Pantoja, I. (2015). Ethics and environmental justice in the Mexican Constitutional State. In J. R. Jiménez Gómez (Ed.), Ethics and justice. Atemporary reflections and proposals. Mexico: Porrúa.

SEMARNAT (Ministry of the Environment and Natural Resources). (2009a). National program for the prevention and management of waste. Retrieved from http://www.semarnat.gob.mx/informacionambiental/publicaciones/Publicaciones/ SEMARNAT\%20Resumen\%20Ejecutivo\%2009.pdf

SEMARNAT (Ministry of the Environment and Natural Resources). (2009b). Strategic program on natural capital. Retrieved from http://elearning.semarnat.gob.mx/cte/MATERIALESAPOYO/DERECHO\%20AMBIENTAL/Contenidos/Documentos\% 20oficiales/Programa\%20Estrat\%C3\%A9gico\%20sobre\%20el\%20Capital\%20Natural.doc 